\title{
The Factors Affecting Specialty Preference and Job Satisfaction of Medical Residents
}

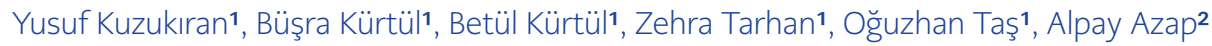 \\ 1 Ankara University School of Medicine, Ankara, Turkey \\ 2 Department of Infectious Diseases and Clinical Microbiology, Ankara University School of Medicine, Ankara, Turkey
}

\begin{abstract}
Objective: The choice of a residency program is one milestone in the professional life of a medical doctor. Residents may be affected by many factors while choosing a specialty, and if some of these factors come true during the residency period, job satisfaction (JS) can be high. We aimed to improve our understanding of the factors affecting the selection of specialties by medical doctors, JS of residents, and factors affecting the JS. Materials and Methods: The study was conducted in a university hospital with 932 beds and 240 residents. Data were collected by a questionnaire consisting of 39 questions to achieve information about demographic characteristics and the factors affecting the preferences of the residents. Participants were also asked to answer the Minnesota Job Satisfaction Questionnaire to obtain their JS scores.

Results: JS of the residents was high in $69.7 \%(n=108)$ of participants. Residents who have chosen their current specialty from within the first three options according to their rank in specialty exam had higher JS ( $\mathrm{p}=0.023$ ). The top factors affecting the residents' preference were an inclination towards the specialty and compliance with personal characteristics. The most crucial factor for choosing a surgical specialty was "an inclination towards the specialty" while "compliance with personal characteristics" was the most crucial factor for choosing non-surgical specialties. The factors that affect Infectious Diseases and Clinical Microbiology (IDCM) residents' preference were the quality of the education, the inclination for the specialty, compliance with personal characteristics and career opportunities. JS of IDCM residents was very high (\%100). For all residents, the inclination for the specialty was more critical than expected economic income $(p<0.001)$.

Conclusion: Inclination towards the specialty is the primary determinant for the preference of specialty among medical doctors. The educational quality of the residency program and career opportunities are also important.

Keywords: Job satisfaction, medical specialty, specialty preference
\end{abstract}

\section{INTRODUCTION}

T ob satisfaction refers to fulfillment of the employees' expectations of their work, the physical environment and the working atmosphere. On the grounds that it is an emotional concept, its perception may differ individually. However, it can still be evaluated with specifically designed tests such as Minnesota Job Satisfaction Ques-
Corresponding Author: Alpay Azap

E-mail:

alpay.azap@medicine.ankara.edu.tr

Received: March 19, 2019

Accepted: May 9, 2019

Published: May 29, 2019

Suggested Citation: : Kuzukıran Y, Kürtül B, Kürtül Betül, Tarhan Z, Taş O, Azap A. The Factors Affecting Specialty Preference and Job Satisfaction of Medical Residents. Infect Dis Clin Microbiol 2019; 1: 42-46.

DOI: 10.5152/idcm.2019.19006 
tionnaire. There are some additional factors such as the basic characteristics of the work, working hours, education, and salary which determine the working conditions and affect job satisfaction $(1,2)$.

The choice of a residency program is one milestone in the professional life of a medical doctor. It definitely marks the start of a new chapter. At the same time, this preference literally refers to a roadside marker of a substantial amount of effort to become a competent doctor after medical education. There are a number of factors affecting a resident's choice. Although these factors vary by country studied and the participants included in the study, some of them such as the quality of education given in the selected residency program, the social prestige of the specialty, the economic income to be obtained and the existence of a role model are mentioned in many studies (3-8).

Residents may be influenced by the aforementioned factors while choosing a specialty and if some of these factors such as quality of education or enjoying the field of work come true during residency period, job satisfaction can expected to be high. In this study, we aimed to improve our understanding about the factors affecting the selection of surgical and non-surgical specialties by medical doctors, job satisfactions of residents, and factors affecting the job satisfaction.

\section{MATERIALS AND METHODS}

The study was conducted in 2018 in a university hospital with 932 beds and 240 residents. All residents who accepted to participate in the study

\section{HIGHLIGHTS}

- Inclination to the specialty was the strongest determinant for the preference of specialty. It was more critical than expected economic income.

- Job satisfaction was not affected by economic income.

- Job satisfaction of infectious diseases and clinical microbiology residents was high. were included. Data were collected by the help of a questionnaire consisting of 39 questions designed by researchers to achieve information about demographic characteristics and the factors affecting the preferences of the residents. These factors were as follows: an inclination to the specialty, "Medicine Specialty Exam (MSE)" score, quality of education, gender, existence of a role model, perception of prestige of the specialty among community and medical doctors, demographic properties of the patients they will deal with, spectrum of the illnesses in the field, career opportunities, economic income of the specialty, personal characteristics, having more information about residency program, and probability of facing to physical violence. Participants were also asked to answer Minnesota Job Satisfaction Questionnaire to obtain their job satisfaction scores. A score of 3 or higher is regarded as high job satisfaction.

The questionnaires were applied to the residents who accepted to participate in the study by face to face interview. Residents were asked to anonymously choose an answer coded in Likert scale from 1 (strongly disagree) to 5 (strongly agree) for each question about factors affecting the preference of specialty. Data analysis conducted by a statistical software (STATA 9.0, StataCorp, College Station, TX, USA). Student's t-test was used to analyse continuous variables and Chi-squared test was used for categorical variables. Mann-Whitney U and Wilcoxon Sign Tests were used to compare ordinal variables. Statistical significance was set as $\mathrm{p}<0.05$.

\section{RESULTS}

Of the 240 residents, 155 (64\%) were interviewed. The mean age was 28 years and $40.6 \%$ were female (Table 1).

Job satisfaction of the residents was high in $69.7 \%$ $(\mathrm{n}=108)$ of participants. Residents who have chosen their current specialty from within the first 3 options according to their rank in MSE had higher job satisfaction ( $p=0.023)$. Job satisfaction is not affected by age, gender, marital status, having children, medical school, specialty, or economic income (Table 1). 
Table 1. Characteristics of the subjects $(\mathrm{N}=155)$ and their effect on job satisfaction

\begin{tabular}{|c|c|c|}
\hline Factor N (\%) & $\begin{array}{l}\text { High job } \\
\text { satisfaction (\%) }\end{array}$ & $p$ \\
\hline Age 28 (mean) & 69.7 & 0.242 \\
\hline $\begin{array}{l}\text { Gender } \\
\text { Female, } 63(40.6) \\
\text { Male, } 92(59.4)\end{array}$ & $\begin{array}{l}73.0 \\
68.4\end{array}$ & 0.544 \\
\hline $\begin{array}{l}\text { Residency program } \\
\text { Surgical, } 63 \text { (40.6) } \\
\text { Non-surgical, } 92 \text { (59.4) } \\
\text { IDCM }, 7 \text { (4.5) }\end{array}$ & $\begin{array}{l}73.0 \\
68.4 \\
100\end{array}$ & 0.544 \\
\hline $\begin{array}{l}\text { Marital status } \\
\text { Married, } 62(40.0) \\
\text { Single, } 93(60.0)\end{array}$ & $\begin{array}{l}66.1 \\
73.1\end{array}$ & 0.351 \\
\hline $\begin{array}{l}\text { Having a child } \\
\text { With children, } 22(14.2) \\
\text { No children, } 133(85.8)\end{array}$ & $\begin{array}{l}72.7 \\
69.9\end{array}$ & 0.790 \\
\hline $\begin{array}{l}\text { Medical school graduation } \\
\text { Same institution (Ankara University), } 43 \text { (27.7) } \\
\text { Other institutions, } 112 \text { (72.3) }\end{array}$ & $\begin{array}{l}74.4 \\
68.7\end{array}$ & 0.489 \\
\hline $\begin{array}{l}\text { MSE ranking } \\
\text { First three, } 125(80.6) \\
4^{\text {th }} \text { or lower ranking, } 30 \text { (19.4) }\end{array}$ & $\begin{array}{l}74.4 \\
53.3\end{array}$ & 0.023 \\
\hline $\begin{array}{l}\text { Economic income } \\
>1200 \text { USD per month, } 58(37.4) \\
<1200 \text { USD per month, } 97(62.6)\end{array}$ & $\begin{array}{l}72.4 \\
69.0\end{array}$ & 0.659 \\
\hline
\end{tabular}

* Infectious Diseases and Clinical Microbiology

Table 2. Factors affecting the preference of specialty choice among medical residents

\begin{tabular}{|l|c|}
\hline $\begin{array}{l}\text { Top five factors influencing preference of } \\
\text { specialty choice }\end{array}$ & $\begin{array}{c}\text { Mean Score } \\
(1-5)\end{array}$ \\
\hline An inclination to the specialty & 4.07 \\
\hline Compliance with personal characteristics & 4.05 \\
\hline Educational quality of residency program & 3.92 \\
\hline Career opportunities in specialty & 3.58 \\
\hline Having more information about residency program & 3.30 \\
\hline
\end{tabular}

Among all residents, the top factors affecting the residents' preference of specialty were the inclination to the specialty and compliance with personal characteristics. (Table 2)

The most important factor for choosing a surgical specialty was "an inclination to the specialty" while "compliance with personal characteristics" was the most important factor for choosing non-surgical specialties. Career opportunities $(\mathrm{p}=0.026)$, social prestige $(p=0.025)$ and prestige among colleagues $(p=0.024)$ were more influential on preference of surgical residents than they are among non-surgi$\mathrm{cal}$ residents. Flexible working conditions $(\mathrm{p}=0.024)$ and probability of having free time $(\mathrm{p}=0.035)$ were more effective factors among non-surgical residents.

At their specialty preference, female residents consider the score of "MSE" ( $p=0.005)$ and social prestige $(p=0.002)$ more than the male residents. An inclination to the specialty $(\mathrm{p}=0.032)$, career opportunities ( $p=0.006)$, educational quality $(p=0.003)$, prestige among colleagues $(p=0.002)$ and the physical condition of the working area $(p=0.035)$ were more influential for male residents.

In accordance with non-surgical specialties, the factors that affect Infectious Diseases and Clinical Microbiology (IDCM) residents' preference were the quality of the education, an inclination to the specialty, compliance with personal characteristics and career opportunities. Social prestige was the least affecting factor for IDCM residents. Finally, job satisfaction of IDCM residents was very high (\%100).

Additional comparisons of individual parameters better defined the most influential factors for residents' preferences. These were: Inclination to the specialty was more important than economic income $(p<0.001)$, impressions obtained in medical school was more important than the existence of a role model $(p<0.001)$, physical conditions of expected working environment was more important than flexible working conditions $(\mathrm{p}=0.002)$ and social relations at working environment was more important than flexible working conditions $(p<0.001)$. 


\section{DISCUSSION}

This study revealed a high job satisfaction among all resident physicians. There was a significant correlation between Job Satisfaction and "MSE ranking". To specialize in a particular subject, medical doctors must take an exam called Medical Specialty Exam (MSE) in Turkey. MSE is a central exam organized twice a year by Turkish Government. Medical doctors list their 14 choices among residency programs and they are placed to one of them according to the score they get at MSE. In our study, the job satisfaction of the participants who were placed to a program which was among the first three ranks of MSE choices was significantly higher. There was no correlation between job satisfaction and age, gender, medical school, marital status, or economic income (Table 1). High job satisfaction among residents in our study may be based on the fact that many of the participants (80.6\%) were placed to one of the first three rank of MSE choices.

Career opportunities, social prestige and respectability among colleagues which are found to be important factors that affect the preference of specialty in our study, were also shown by Azzizzadeh and Grigg $(5,9)$. Unlike Azzizzadeh's study, economic income was not an important factor for choosing surgical specialties in our study. Flexible working conditions and the probability of having more free time were shown to effect specialty choices of medical students (10) and in our study, these factors are found to be more effective on the preference of specialty among non-surgical residents. This may be related to stressful atmosphere and prolonged working hours in surgical residency programmes, which are shown as deterrent factors for surgical specialties in literature (11-13).

The number of events which involve physical and/ or verbal violence against healthcare workers and their reflections to media has increased over the years in Turkey (14). Many of these events are seen in emergency rooms and surgical wards (15). To the best of our knowledge, the effect of violence on the preference of residency program is unknown. In our study, the participants stated that the probability of facing to physical violence did not play an important role on their preference.
Table 3. Factors affecting the preference of specialty among surgical and non-surgical residents

\begin{tabular}{|l|c|c|c|}
\hline \multirow{2}{*}{$\begin{array}{l}\text { Factors affecting } \\
\text { the preference } \\
\text { of specialty }\end{array}$} & $\begin{array}{c}|c| \\
\text { Surgical } \\
\text { residents } \\
\mathrm{N}(\%)\end{array}$ & \begin{tabular}{c}
\multirow{2}{*}{$\begin{array}{c}\text { Non-surgical } \\
\text { Residents } \\
\mathrm{N}(\%)\end{array}$} \\
yynn
\end{tabular} & \multirow{2}{*}{$\mathrm{P}$} \\
\hline $\begin{array}{l}\text { An inclination to } \\
\text { the specialty }\end{array}$ & 4.24 & 3.96 & 0.097 \\
\hline $\begin{array}{l}\text { Compliance with } \\
\text { personal characteristics }\end{array}$ & 4.11 & 4.00 & 0.558 \\
\hline Career opportunities & 3.84 & 3.40 & 0.026 \\
\hline Social prestige & 2.68 & 2.14 & 0.025 \\
\hline $\begin{array}{l}\text { Prestige among } \\
\text { colleagues }\end{array}$ & 2.89 & 2.20 & 0.003 \\
\hline $\begin{array}{l}\text { Flexible working } \\
\text { conditions }\end{array}$ & 2.14 & 2.65 & 0.024 \\
\hline $\begin{array}{l}\text { Probability of having } \\
\text { free time }\end{array}$ & 2.37 & 2.90 & 0.035 \\
\hline
\end{tabular}

As opposed to some earlier studies $(6-8,12)$, expected income has no influence on job satisfaction or residency program choice in our study. Our study demonstrated that the physicians consider their inclination to the residency program rather than earning much money. In addition, some studies showed that physicians take the gender distribution into consideration while they choose their specialty $(9,12,16,17)$, but this relationship was not observed in our study. The features of the study population and the methods used may cause these differences between the literature and our study.

Our study has some limitations. First, although it is conducted at one of the biggest training hospitals in Turkey the sample size is quite small. Second, being a single center study it may not represent all the residents in Turkey. Third, high job satisfaction found in the study may originate from the fact that Ibni Sina Hospital is one of the most preferred training center for residents. Further studies done on a national scale can overcome these limitations and give more accurate information about specialty preferences and job satisfaction of medical doctors. 
Inclination to the specialty is the primary determinant for the preference of specialty among medical doctors. Educational quality of the residency program and career opportunities are also important. Working conditions, probability of facing to violence and expected income do not have an influence on the preference of specialty. Job satisfaction measured by Minnesota Job Satisfaction Questionnaire was high in $69.7 \%$ of all residents and 100\% of IDCM residents. These findings can make the administrators of residency programs to understand the motives of residents for choosing or not choosing their programs and give the opportunity to improve their educational activities.
Ethics Committee Approval: Ethics committee approval was received for this study from the Ethics Committee of the Ankara University School of Medicine (Decision Date: February 6, 2018; Decision Number: 72189195-050.03.04-E.6011).

Informed Consent: N/A.

Peer-review: Externally peer-reviewed.

Author Contributions: Concept - A.A.; Design - A.A., Y.K., B.K., B.K., Z.T., O.T.; Supervision - A.A.; Resources - Y.K., B.K., B.K., Z.T.,
O.T.; Materials - Y.K., B.K., B.K., Z.T., O.T.; Data Collection and/or Processing - Y.K., B.K., B.K., Z.T., O.T.; Analysis and/or Interpretation - A.A., Y.K.; Literature Search - Y.K., B.K., B.K., Z.T., O.T.; Writing Manuscript - A.A.,Y.K., B.K., B.K., Z.T., O.T.; Critical Reviews - A.A., Y.K.

Conflict of Interest: The authors have no conflict of interest to declare.

Financial Disclosure: The authors declared that this study has received no financial support.

\section{REFERENCES}

1 Çetinkanat C. Örgütlerde Güdülenme ve Iş Doyumu. Ankara: Anı, 2000; 2000.

2 Bilgiç R. İş Özellikleri Kuramı: Geniş Kapsamlı Gözden Geçirme. Türk Psikoloji Yazılan 2008; 11: 66-77.

3 Dorsey ER, Jarjoura D, Rutecki GW. Influence of controllable lifestyle on recent trends in specialty choice by US medical students. JAMA 2003; 290: 1173-8.

4 Burack JH, Irby DM, Carline JD, Ambrozy DM, Ellsbury KE, Stritter FT. A study of medical students' specialty-choice pathways: trying on possible selves. Acad Med 1997; 72: 534-41.

5 Azizzadeh A, McCollum CH, Miller CC 3rd, Holliday KM, Shilstone HC, Lucci A Jr. Factors influencing career choice among medical students interested in surgery. Curr Surg 2003; 60: 210-3.

6 Hauer KE, Durning SJ, Kernan WN, et al. Factors associated with medical students' career choices regarding internal medicine. JAMA 2008; 300: 1154-64.

7 Sierles F, Dinwiddie S, Patroi D, Atre-Vaidya N, Schrift M, Woodard J. Factors affecting medical student career choice of psychiatry from 1999 to 2001. Acad Psychiatry 27: 260-8.

8 iker BF, Zeh M. Relative income expectations, expected malpractice premium costs, and other determinants of physician specialty choice. J Health Soc Behav 1998; 39: 152.

9 Grigg M, Arora M, Diwan AD. Australian medical students and their choice of surgery as a career: a review. ANZ J Surg 2014; 84: 653-5.
10 Abdulrahman M, Makki M, Shaaban S, Al Shamsi M, Venkatramana M, Sulaiman N, et al. Specialty preferences and motivating factors: A national survey on medical students from five uae medical schools. Educ Health (Abingdon) 2016; 29: 231-43.

11 Cleland JA, Johnston PW, Anthony M, Khan N, Scott NW. A survey of factors influencing career preference in new-entrant and exiting medical students from four UK medical schools. BMC Med Educ 2014; 14: 151.

12 Schmidt LE, Cooper CA, Guo WA. Factors influencing US medical students'decision to pursue surgery. J Surg Res 2016; 203: 64-74.

13 Marshall DC, Salciccioli JD, Walton SJ, Pitkin J, Shalhoub J, Malietzis G. Medical student experience in surgery influences their career choices: a systematic review of the literature. J Surg Educ 2015; 72: 438-45.

14 Arpaci HE, Canbaz M, Celikten B, Demirel C, Kara A, Ergonul O. Stop the violence against health care workers in Turkey: Mert Canbaz. Eur J Public Health 2014; 24(Suppl. 2): cku165-124.

15 Ayranci U, Yenilmez C, Balci Y, Kaptanoglu C. Identification of violence in Turkish health care settings. J Interpers Violence 2006; 21: 276-96.

16 Fukuda Y, Harada T. Gender differences in specialty preference and mismatch with real needs in Japanese medical students. BMC Med Educ 2010; 10: 15.

17 Van Der Horst K, Siegrist M, Orlow P, Giger M. Residents' reasons for specialty choice: influence of gender, time, patient and career. Med Educ 2010; 44: 595-602. 